\title{
“BERNAFAS KEMBALI": SARANA OLAHRAGA PASCA COVID
}

\author{
Michelle Adeline ${ }^{1)}$, Budi A Sukada ${ }^{2)}$ \\ 1)Program Studi S1 Arsitektur, Fakultas Teknik, Universitas Tarumanagara,chelleadeline1998@gmail.com \\ 2) Program Studi S1 Arsitektur, Fakultas Teknik, Universitas Tarumanagara, budisukada@yahoo.com
}

Masuk: 19-01-2021, revisi: 21-02-2021, diterima untuk diterbitkan: 26-03-2021

\begin{abstract}
Abstrak
Penyakit COVID-19 adalah penyakit menular yang disebabkan oleh virus Corona yang ditemukan pada tanggal 31 Desember 2019, kasus pertama di Wuhan, Tiongkok. Virus ditransmisikan melalui droplet yang dihasilkan saat orang yang terinfeksi batu, bersin, atau menghembuskan nafas. Droplet ini terlalu berat dan tidak bisa bertahan di udara, sehingga dengan cepat jatuh dan menempel pada lantai atau permukaan lainnya. Pandemi COVID19 yang dihadapi secara global pada tahun 2020 menyebabkan perubahan signifikan terhadap pola hidup masyarakat dunia, mulai dari karantina mandiri, menerapkan budaya social distancing, merubah pola hidup yang lebih higenis dan sehat dibandingkan tahuntahun sebelumnya. Pola hidup ini terjadi sebagai mitigasi atau upaya dalam mencegah penyebaran virus. Perubahan ini menyebabkan fenomena baru yang disebut sebagai Kenormalan baru COVID-19. Masyarakat dunia menjadi lebih sadar akan pentingnya menjaga kesehatan dan kebersihan. Masyarakat juga mulai melakukan kegiatan-kegiatan olahraga seperti bersepeda, berolahraga dari rumah, jogging, dan aktivitas lainnya sebagai upaya untuk memperkuat daya tahan tubuh. Dengan kegiatan baru yang banyak dilakukan masyarakat maka diperlukan sarana olahraga yang dapat memfasilitasi aktivitas olahraga masyarakat sehingga masyarakat yang lebih suka berolahraga di luar rumah atau masyarakat yang tidak punya alat-alat olahraga dapat menggunakan sarana ini dengan fasilitas-fasilitas bangunan yang sesuai dengan standar protokol kesehatan yang ada di Indonesia.
\end{abstract}

Kata kunci: COVID-19; Kenormalan Baru; Pola Hidup.

\begin{abstract}
COVID-19 is a contagious disease caused by SARS-CoV-2. The first case was identified in Wuhan, China, in $31^{\text {st }}$ December 2019. The virus has spread worldwide, causing an ongoing pandemic. Small droplets containing the virus can spread form an infected person's nose and mouth as they berathe, cough, and sneeze. The virus may also spread via contaminated surfaces. COVID-19 pandemic that is being faced globally in 2020 has caused significant changes to human lifestyle, starting from self-quarantine, implementing social distancing, people became more hygienic and living a healthier lifestyle than the previous years. This lifestyle occurs as an effort to prevent the spread of the virus. This change causes a new phenomenon known as the New Normal in COVID-19. People are now aware of the importance of maintaining good health and hygiene. The community also started doing sports activities such as cycling, exercising from home, jogging, and other activities in an effort to strengthen endurance. With many new activities carried out by the community, sports facilities are needed that can facilitate community sports activities so that people who prefer to exercise outside the home or people who do not have sports equipment can use this facility with building facilities that comply with standard health protocols. in Indonesia.
\end{abstract}

Keywords: COVID-19; Lifestyle; New Normal. 


\section{PENDAhULUAN}

\section{Latar Belakang}

Pandemi COVID-19 merupakan peristiwa yang menyebabkan masyarakat menjadi lebih mudah stress. Ketakutan dan anxietas akan penyakit ini menyebabkan seorang individu menjadi lebih emosional baik orang dewasa ataupun anak kecil. Social dan physical distancing dapat menyebabkan seseorang merasa terisolasi dan merasa kesepain sehingga meningkatkan stress dan kecemasan. Namun, untuk mengatasi stress dan cemas yang berlebihan masyarakat mulai menjaga kesehatannya serperti berolahraga, pola makan yang teratur, dan istirahat yang cukup.

Aktivitas olahraga dipercaya dapat mengurangi dampak stress pada seseorang, karena sebuah studi mengatakan bahwa dengan berolahraga secara rutin tubuh akan memproduksi hormon serotonin dan endorfin yang berfungsi dalam mengurangi efek buruk dari stress, rasa sakit, dan meningkatkan respons kekebalan tubuh. Namun, karena adanya peraturan PSBB menyebabkan penutupan gym, secara massal sebagai tindakan untuk mencegah bertambahhnya orang yang terinfeksi, tidak semua orang dapat melakukan kegiatan olahraga di rumah, karena keterbatasan alat-alat olahraga.

Penutupan ini disebabkan karena fasilitas umum yang ada tidak memiliki standar keamanan dari protokol kesehatan yang ada. Sebagian besar fasilitas umum haya mewajibkan penggunanya untuk mengenakan masker, dan hanya menambah partisi-partisi tanpa memberi solusi desain secara arsitektural.

\section{Rumusan Permasalahan}

a. Bagaimana arsitektur dapat merespon desain yang aman untuk berinteraksi sosial ditengah pandemi?

b. Bagaimana arsitektur dapat merespon dan mewadahi ruang olahraga, dan komunitas baru karena pandemi COVID-19 dengan penerapan Social Distancing?

\section{Tujuan}

Menciptakan wadah yang menunjang hobi atau minat masyarakat dalam keaktifan berolahraga, untuk meningkatkan kesasdaran masyarakat pentingnya pola hidup sehat di tengah pandemi. Selain itu juga menjadi wadah untuk masyarakat, dan komunitas-komunitas untuk berinteraksi sosial.

\section{KAJIAN LITERATUR}

\section{Dwelling menurut Etimologi}

Kata Dwelling dalam bahasa Inggris kunonya adalah "dwellan" yang berarti mengembara (to wander) dan bertahan hidup (to linger). Secarea filosofis, kata dwelling memberikan makna bahwa: "Untuk bertahan hidup, tidak dapat dilakukan dengan berdiam diri atau menetap tetapi harus mengembara".

\section{Dwelling menurut Martin Heidegger}

Dwelling adalah karakter dari sesuatu yang "ada", aberelasi dnegan manusia di dunia. "Ada" disebut sebagai penyebab segala sesuatu yang ada, "Ada" merupakan tempat "beradanya". "Dasein" dan "das Seiende". "Ada" merupakan satu "peristiwa" yang menyebabkan nberadanya segala sesuat (van Peursen, 1980:96). Segala sesuatu yang "Ada" berdiri di depan horizonnya. Dengan demikian "Ada" dan "Waktu" saling berkaitan (van Peursen, 1980:245). Tinggal di rumah, tidak hanya berada di dalamnya secara spasial dalam arti hanya menyisir dan berputar dalam lingkungan rumah saja. Sebaliknya, rumah sebagai sesuatu yang "Ada" adalah milik dunia, dan orang yang menghuni didalamnya harus keluar untuk melihat "langit-langit dunia". Kata lama dari "Bauen" To build, dwell, also to care for, cherish, protect, preserve, nurture. 


\section{Dwelling menurut Christian Norberg Schulz}

To dwell, berarti pembentukkan hubungan antara manusia dan lingkungan tertentu. Manusia menemukan dirinya ketika menetap, dan keberadaannya di dunia dengan demikian ditentukkan. Di sisi lain, manusia juga seorang pengembara. Terdapat 4 mode $d$ welling yaitu;

- The settlement; tahap dimana tempat tinggal terjadi.

- Urban Space; tahap dimana manusia berkupul dalam keanekaragamannya.

- Institution / Public Dwelling; dimana rasa memiiliki forum untuk pemikiran yang sama di ekspresikan.

- House / Private Dwelling; dimana kediaman pribadi berlangsung, didirikan sebagai tempat berlindung, berekspresi, dan membangun kenangan.

\section{Kesimpulan Dwelling}

Manusia terlempar pada dunia tanpa memilih, dalam keberadaannya menuju kepada kematian. Manusia dalam menjalani hidupnya berkaitan dengan dwelling. Fenomena dwelling merupakan proses dimana manusia berusaha untuk bertahan hidup (survival) dengan kondisi geografis ataupun ancaman lainnya sehingga berkaitan erat dengan arsitektur. Hal ini berubah menjadi budaya, dan habit. Awal mula dwelling berasal dari sebuah shelter untuk bertahan hidup, kemudian perlahanlahan dwelling berubah menjadi ruang untuk manusia berkumpul bersama untuk melakukan kegiatan tertentu.

\section{Sarana Umum}

Sarana adalah segala sesuatu yang dipakai sebagai alat dalam mencapai makna dan tujuan. Prasarana adalah segala sesuatu yang merupakan penunjang utama terselenggaranya suatu proses (Kamus Besar Bahasa Indonesia). Sarana Prasarana adalah alat secara fisik untuk menyampaikan isi pembelajaran (Sagne dan Brigs dalam Latuheru, 1988:13)

\section{Sarana Olahraga}

Menurut Peraturan Pemerintah No. 2 Tahun 2017 Pasal 1; Sarana adalah segala sesuatu yang dapat dipakai sebagai alat dalam mencapai suatu tujuan. Prasarana adalah segala sesuatu yang merupakan penunjang utama terselenggaranya suatu proses. Sarana Prasarana adalah alat secara fisik untuk menyampaikan isi pembelajaran (Sagne dan Brigs dalam Latuheru, 1988:13).

\section{Sport Center}

Dalam KBBI, gelanggang memiliki pengertian ruang atau lapangan tempat tinju, berolahraga, dan sebagainya. Sedangkat olahraga ialah gerak badan untuk menguatkan dan menyehatkan tubuh. Menurut buku Design for Sport (A. Perin Gerald, 1981), Sport Center adalah sebuah peerluasan dari skala tertentu yang dapat diasosiasikan dengan satu sport hall yang menyediakan fasilitas lainnya yang berguna bagi masyarakat. Sport Center dapat berupa gedung olahraga yang mewadahi kegiatan olahraga baik kegiatan latihan, rekreasi, maupun kompetitif.

\section{Ruang Publik}

Ruang publik secara umum merupakan suatu ruang terbuka yang dapat mendukung kebutuhan manusia akan tempat-tempat berkkumpul dan wadah untuk berinteraksi dengan manusia dalam melakukan aktivitas bersama. Ruang publik merupakan suatu wadah yang dapat menampung aktivitas tertentu dari masyarakatnya, baik secara individu maupun secara kelompok, dimana bentuk ruang publik ini sangat tergantung pada pola dan susunan massa bangunan. (Rustam Hakim, 1987).

Carr dkk (1992), ruang publiik harus memiliki tiga hal yaitu responsif, demokratis, dan bermakna. Responsif artinya ruang yang dapat digunakan memilki fungsi lingkungan hidup. Ruang publik adalah lokasi yang didesain dengan akses yang besar, sebagai tempat berkumpul manusia. Pengguna ruang publik satu sama lain mengikuti norma-norma yang berlaku setempat (Roger Scurton, 1984). 


\section{External Public Space}

Ruang publik yang dapat diakses oleh semua orang (publik) seperti taman kota, alun-alun, jalur pejalan kaki, dan lain sebagainya.

\section{Internal Public Space}

Ruang publik berupa fasilitas umum yang dikelola pemerintah dan dapat diakses oleh warga secara bebas tanpa ada batasan tertentu, seperti kantor pos, kantor polisi, rumah sakit dan pusat pelayanan warga lainnya.

\section{External and Internal "quasi" Public Space}

Berupa fasilitas umum yang biasanya dikelola oleh sektor privat (Swasta) dan memiliki batasan atau aturan yang harus dipatuhi warga, seperti mall, diskotik, restoran dan lain sebagainya.

\section{METODE}

Metode pengumpulan data yang digunakan pada penelitian ini adalah metode kualitatif, dengan melakukan studi kepustakaan serta preseden terhadap bangunan-bangunan olahraga, dan bangunan yang sudah memenuhi protokol kesehatan COVID-19, serta untuk mempelajari sirkulasi dan kebutuhan ruang yang ada. Sementara untuk metode desain menggunakan metode preseden, dengan mempelajari bangunan-bangunan dengan fungsi yang sama sebagai studi kasus untuk desain proyek.

\section{DISKUSI DAN HASIL}

Proyek Sarana Olahraga Pasca COVID: Bernafas Kembali ini menjadi sebuah respon dalam mengatasi kesehatan fisik maupun mental masyarakat yang terdampak dari perubahan hidup di masa pandemi COVID-19, dan dapat beraktivitas tanpa masker. Proyek ini lokasinya di Jalan Boulevard Gading Raya, dan Jalan Bukit Gading Raya 1, Kelapa Gading Barat, Jakarta Utara. Alasan memilih lokasi ini karena Jakarta Utara memiliki jumlah masyarakat aktif olahraga tertinggi dibandingkan wilayah lainnya, yaitu sebanyak 5.323.459 orang, dan memilih di kawasan Kelapa Gading karena target utama pengguna adalah generasi $Y$ dan generasi $Z$. Tapak yang dipilih berada di kawasan komersil-hunian di Kelapa Gading Barat, Jakarta Utara. Lokasi tapak di Jalan Boulevard Gading Raya dan Jalan Bukit Gading Raya 1 ini dipilih berdasarkan kriteria-kriteria yaitu: Aksesibilitas yang baik, Lokasi yang strategis, dan Lokasi sesuai berdasarkan isu dan data yang ada

Tabel 1. Perbandingan Fungsi atau Peruntukkan Zonasi Berdasarkan RTRW 2030

\begin{tabular}{|c|c|c|c|c|c|c|}
\hline \multicolumn{2}{|c|}{ PUNGSI KOTAMAOVA } & $\begin{array}{l}\text { JAKARTA } \\
\text { BARAT }\end{array}$ & $\begin{array}{l}\text { JAKARTA } \\
\text { PUSAT }\end{array}$ & $\begin{array}{l}\text { JAKARTA } \\
\text { SELATAN }\end{array}$ & $\begin{array}{l}\text { JAKARTA } \\
\text { TIMUR }\end{array}$ & $\begin{array}{l}\text { JAKARTA } \\
\text { UTARA }\end{array}$ \\
\hline \multirow{2}{*}{$\begin{array}{l}\text { PERKANTORAN, } \\
\text { PERDAGANGAN, } \\
\text { DAN JASA. }\end{array}$} & KB TINGGI & $7.81 \%$ & $12.47 \%$ & $6.92 \%$ & $3.33 \%$ & $4.56 \%$ \\
\hline & KB RENDAH & * & - & $0.96 \%$ & $1.85 \%$ & - \\
\hline \multicolumn{2}{|c|}{ PEMERINTAHAN } & $0.17 \%$ & $2.42 \%$ & $0.54 \%$ & $1.44 \%$ & $0.28 \%$ \\
\hline \multicolumn{2}{|l|}{ PEMUKIMAN } & $4.64 \%$ & $11.92 \%$ & $12.55 \%$ & $6.57 \%$ & $5.82 \%$ \\
\hline \multicolumn{2}{|c|}{ AREA PEMUKIMAN HIJAU } & $0.47 \%$ & $\cdot$ & $5.17 \%$ & $2.17 \%$ & $2.12 \%$ \\
\hline \multicolumn{2}{|c|}{ AREA HIJAU BUDIDAYA } & $2.80 \%$ & $2.50 \%$ & $3.00 \%$ & $4.00 \%$ & $0.52 \%$ \\
\hline \multicolumn{2}{|c|}{ AREA HIJAU LINDUNG } & $\cdot$ & $\cdot$ & $\cdot$ & . & $0.58 \%$ \\
\hline \multicolumn{2}{|c|}{ INDUSTRI \& PERGUDANGAN } & $0.58 \%$ & $\cdot$ & - & $1.48 \%$ & $4.57 \%$ \\
\hline
\end{tabular}

Sumber: RTRW 2030

Dalam radius kawasan $800 \mathrm{~m}$, sebagian besar kawasan merupakan zona residensi, komersil, dan pergudangan. Tapak ini dekat dengan gedung Metrologi, Sekolah Penabur International, Masjid AnNizam Kawasan ini area penghijauannya sangat sedikit, karena sudah padat oleh perumahan, pergudangan dan fungsi komersil lainnya. Dengan luas tapak $5.785 \mathrm{~m}^{2}$ proyek ini terdapat fungsifungsi seperti gym, healthy café, kelas sepeda statis, jogging track dan bike track. 


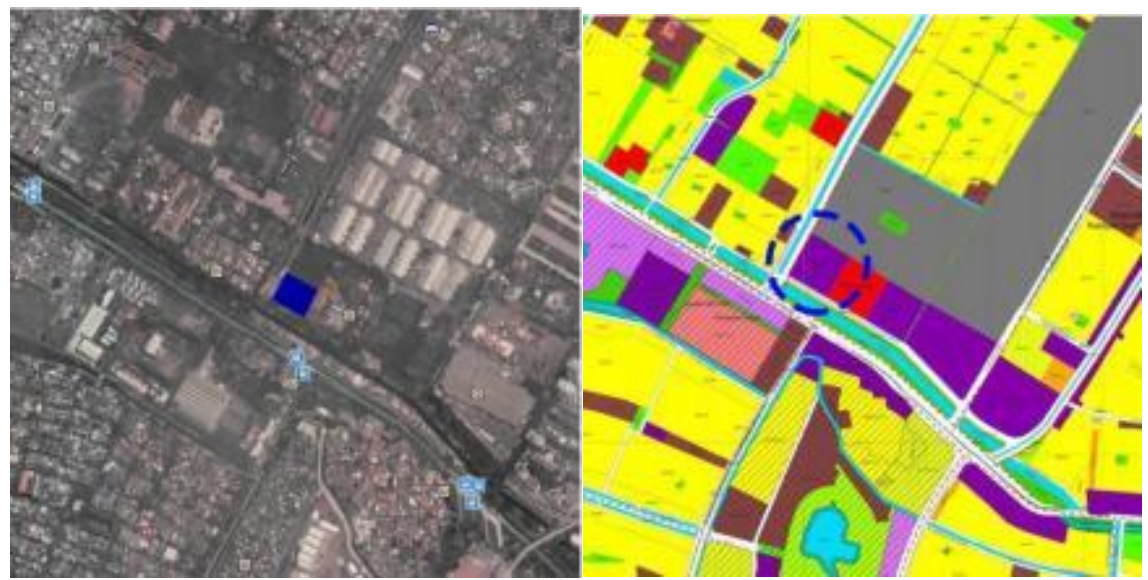

Gambar 1. Lokasi Tapak

Sumber: Jakarta Satu, 2020

Tapak yang digunakan merupakan zona perkantoran, perdagangan, dan jasa dengan kode 02.001.K1. Dengan KDB sebesar 50\%, KLB 2, KDH 35\%, KB 4, KTB 50, dengan tipe bangunan tunggal. Luas tapak sebesar $5.785 \mathrm{~m}^{2}$.

$$
\begin{array}{ll}
\text { KDB } & : 50 \% \times 5.785 \mathrm{~m}^{2}=2.890 \mathrm{~m}^{2} \\
\text { KLB } & : 2 \times 5.785 \mathrm{~m}^{2}=11.570 \mathrm{~m}^{2} \\
\text { KDH } & : 35 \% \times 5.785 \mathrm{~m}^{2}=2.024 \mathrm{~m}^{2} \\
\text { KTB } & : 50 \% \times 5.785 \mathrm{~m}^{2}=2.890 \mathrm{~m}^{2}
\end{array}
$$

Perizinan: Lapangan Olahraga, Gedung Olahraga, Pusat Olahraga dan Kesehatan Jasmani, Spa dan Fitness, Café, Restoran, Pusat Jajan, Perkantoran, Rumah Panti, Mall, Hotel.

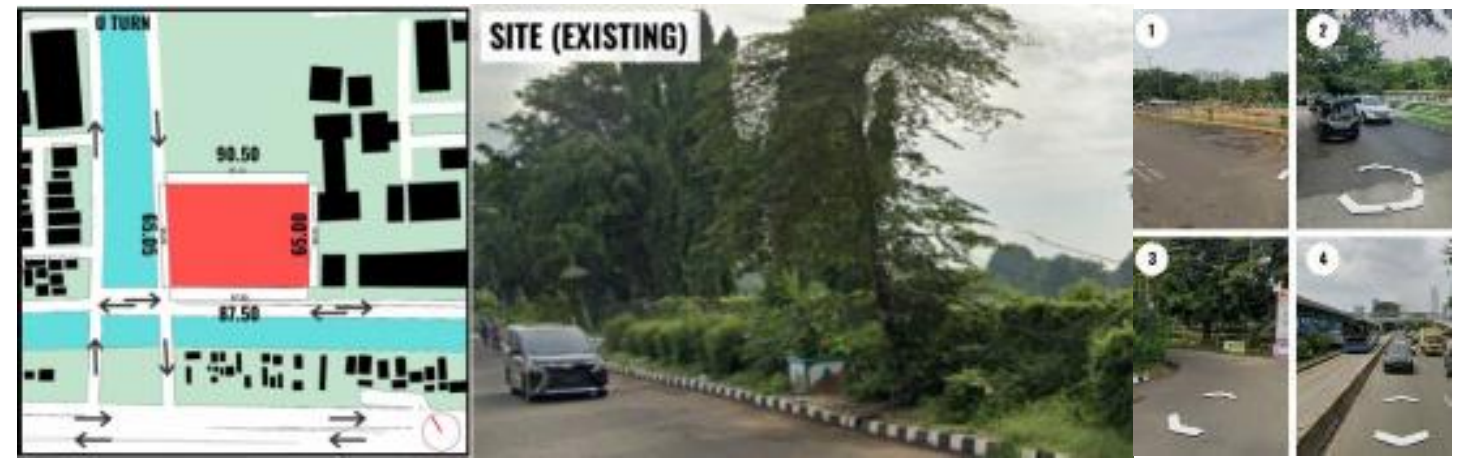

Gambar 2. Site Eksisting Sumber: Google Earth, 2020

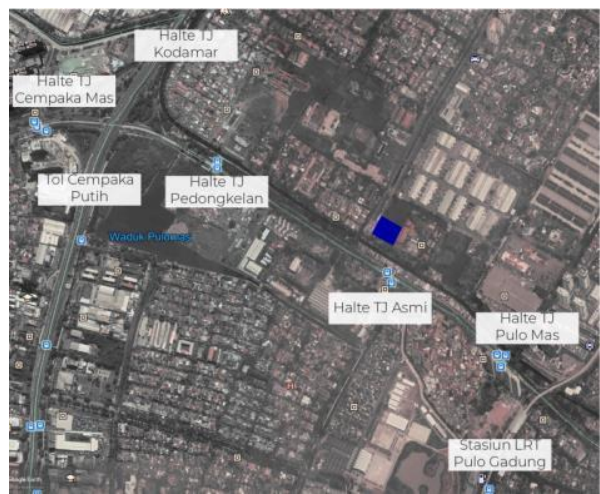

Gambar 3. Pemetaan Aksesibilitas Transjakarta dan kendaraan pribadi Sumber: Google Earth, 2020 
Jakarta Utara, di kawasan Kelapa Gading Barat terdapat titik integrasi antar Transjakarta-LRT, di Pulomas. Terdapat juga Transjakarta Halte Bermis, ASMI 1, ASMI 2, Pedongkelan, Stasiun LRT Kelapa Gading Boulevard, dan Stasiun LRT Mall Kelapa Gading. Sehingga tapak mudah diakses oleh pengunjung yang menggunakan transportasi umum ataupun dengan kendaraan pribadi. Di kawasan ini juga dekat dengan jalan Tol Cempaka Putih sehingga mudah diakses oleh kendaraan beroda empat.

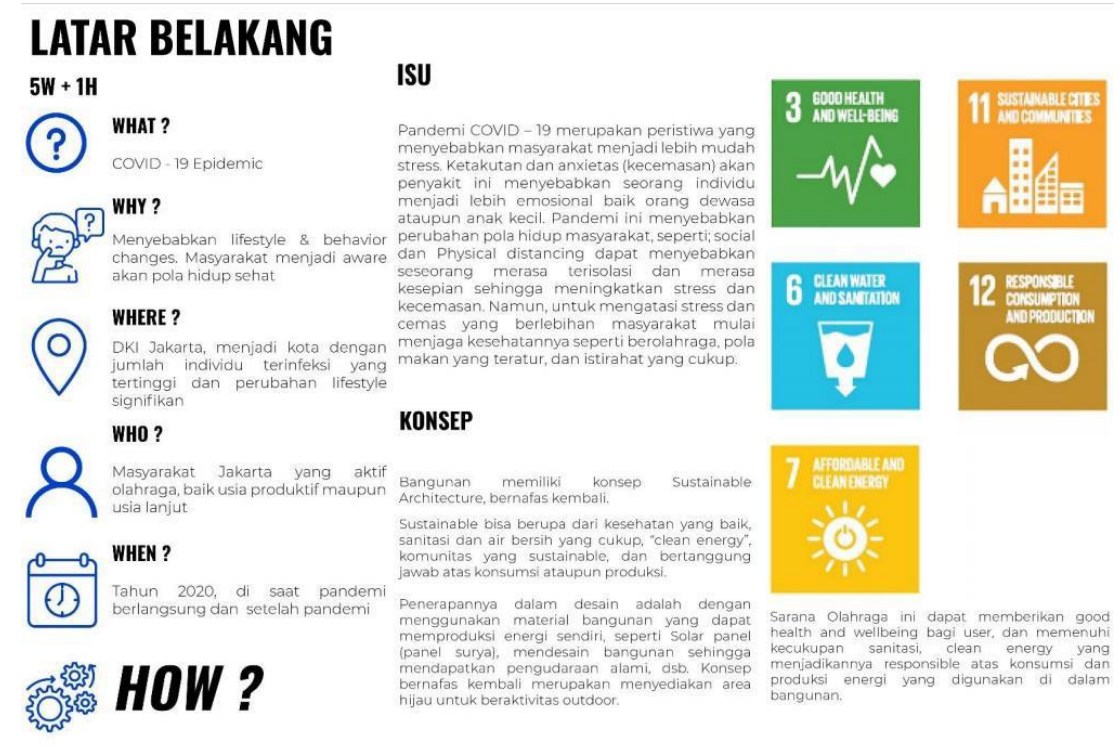

Gambar 4. Konsep bangunan

Sumber: Penulis, 2020

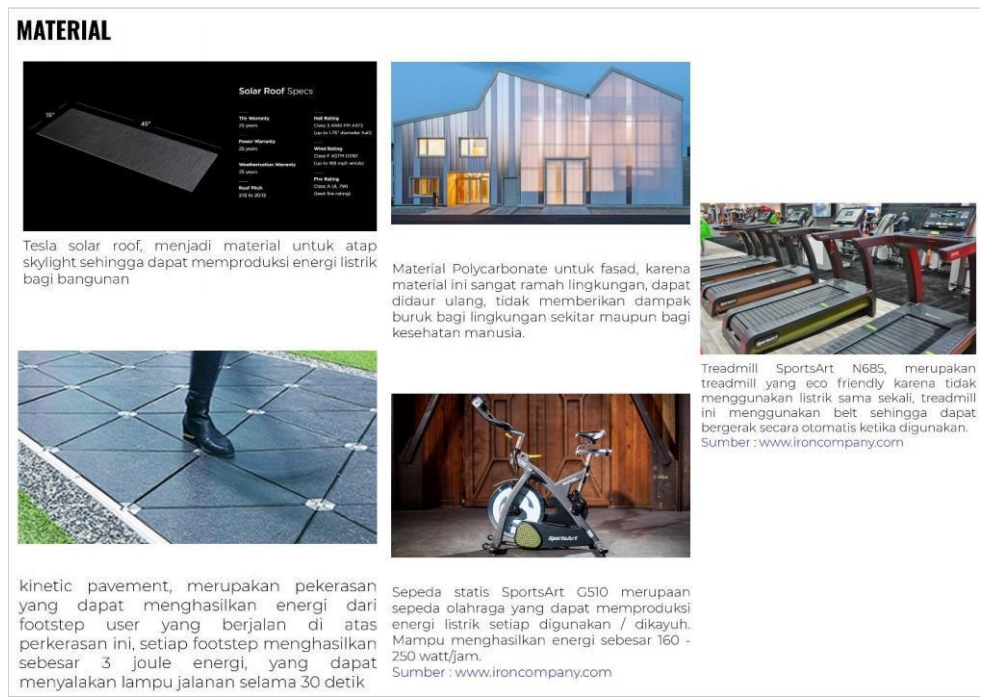

Gambar 5. Gambar Material

Sumber: Tesla, pinterest polycarbonate façade, SportsArt Gym Equipment

Sarana olahraga ini menggunakan konsep "Sustainable Design" dengan menggunakan materialmaterial dan alat-alat olahraga yang ramah lingkungan dan dapat menghasilkan energi listrik untuk digunakan kembali ke bangunan. Material yang digunakan adalah panel surya, sepeda statis penghasil energi listrik, perkerasan kinetik yang menghasilkan energi listrik setiap injakan kaki, dan treadmill yang tidak menggunakan listrik. Sehingga menciptakan komunitas yang sustainable dimana 
kegiatan yang dilakukan menjadi bermanfaat bagi pengunjung bangunan maupun bangunan itu sendiri. Untuk sistem pencegahan virus, pada bagian entrance disediakan area sterilisasi, sehingga pengunjung bangunan dapat melakukan aktifitas tanpa harus mengenakan masker, sehingga bangunan ini memiliki tema "bernafas kembali". Selain itu juga proyek ini memiliki target pengunjung terutama ada generasi $Y$ dan $Z$ karena memiliki potensi untuk terus digunakan di masa depan dan lebih memiliki minat untuk berolahraga dibandingkan generasi $X$ dan generasi Boomer.

\section{TARGET USER}

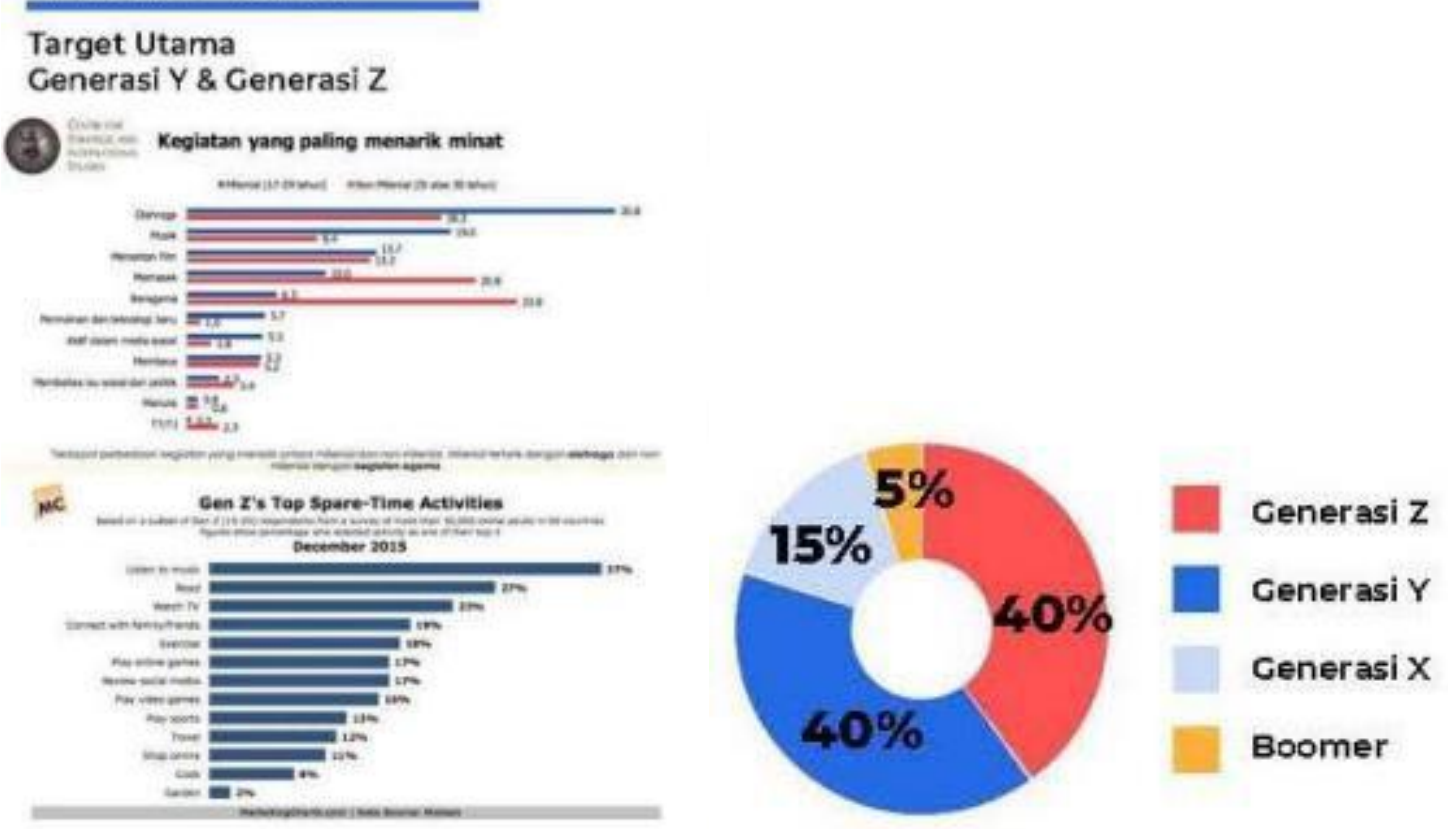

Gambar 6. Target pengunjung

Sumber: Nielsen Les Mills, Center For Strategic and International Studies, dan dokumen pribadi, 2020

Berdasarkan survey dari Nielsen Les Mills, kegiatan yang paling menarik minat kaum generasi $Z$ dan generasi $Y$ saat ada waktu luang adalah aktivitas olahraga, mendengarkan musik, dan membaca. Hal ini menyebabkan potensi generasi $Z$ dan generasi $Y$ yang paling besar untuk menggunakan sarana olahraga di masa depan ditambah dengan meningkatnya kesadaran akan gaya hidup sehat sejak adanya pandemi COVID-19. 


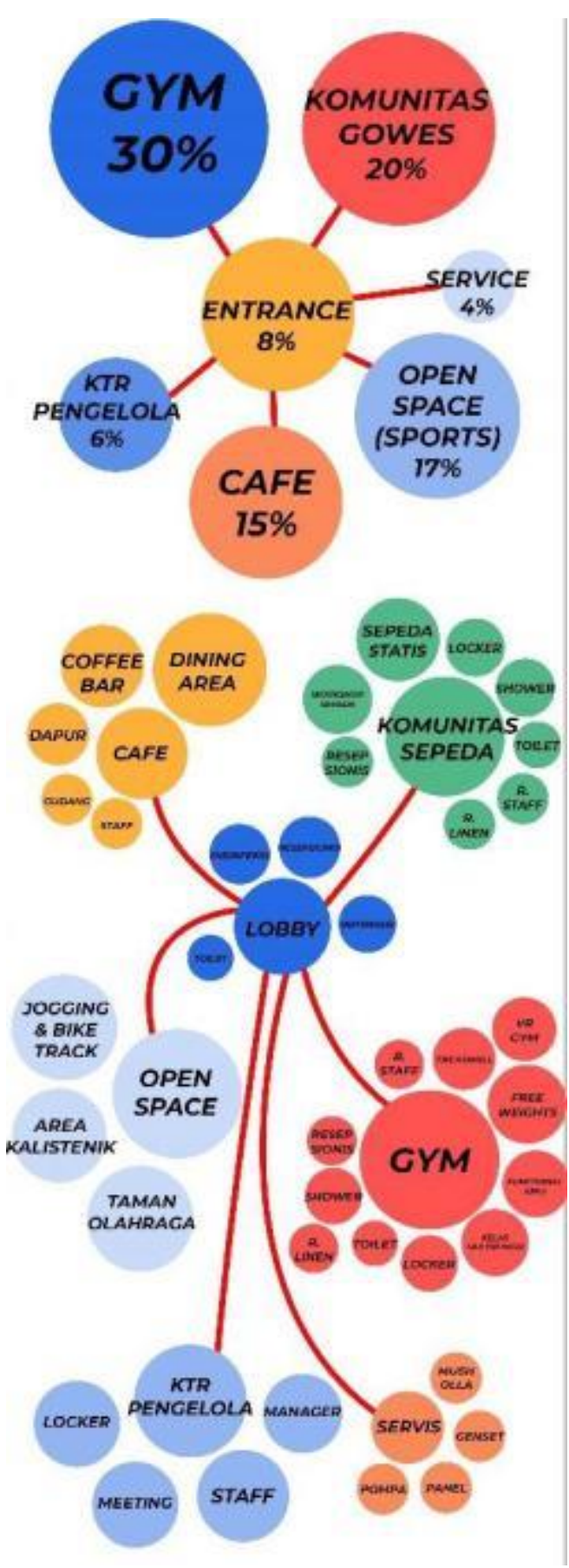

Gambar 7. Hubungan antar Ruang Sumber: Penulis, 2020

Fungsi utama dihubungkan melalui main entrance yang membagi ke 3 massa yaitu area gym, healthy café, dan area komunitas gowes. Alasan menggunakan sirkulasi seperti ini karena area main entrance merupakan area sterilisasi sehingga setiap berpindah ke setiap fungsi, sehingga pengujung bangunan bisa tetap aman ketika menggunakan setiap fungsi bangunannya, dan semua fungsi bangunan juga tetap steril dari penyebaran virus. 


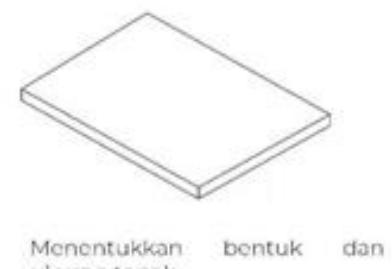

ukuran tapak

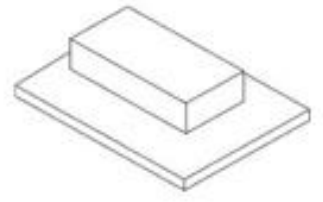

Kemudian mulai membentuk massa awal persogi panjang

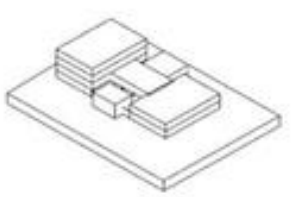

Lalu massa persegi parjang itu dibagi menjad 4 massa seswa zening, entrance. cafe. gym can

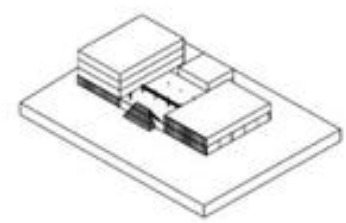

Membentuk icon dari bangunar yaitu paca bagian entrance nyo schingos memberikan kesar megeh saat memasuk barguna

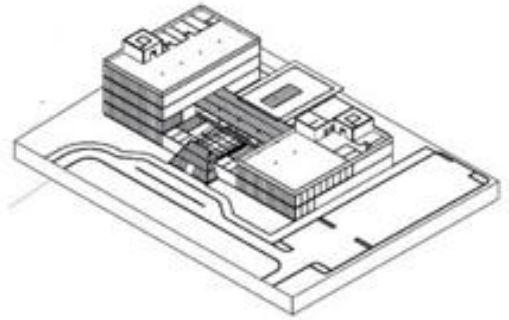

Gambar 8. Proses Gubahan Massa

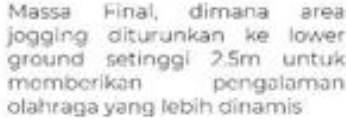

olahteaga yang lebih cinamis

Massa bangunan ini ditentukkan bentuknya berdasarkan bentuk awal dari tapak yang ada,kemudian massa awal nya dibentuk menjadi persegi panjang, yang kemudian persegi panjang tersebut dibagi menjadi 4 massa sesuai dengan zonasi entrance, café, gym, dan komunitas sepeda. Kemudian membentuk icon dari bangunan ini, yaitu di bagian entrance nya memiliki bentuk seperti jurai ayng membeirkan kesan megah saat pengunjung memasuki bangunan ini. Massa Finalnya, terdapat area jogging yang berada diantara massa bangunan ditengah sehingga menciptakan ruang publik berupa courtyard, sehingga pengunjung yang ingin melakukan kegiatan jogging di rute ini dapat mengelilingi seluruh bangunan yang ada dengan pemandangan lansekap courtyard.

Proyek ini memiliki 4 massa, massa di paling depan adalah bangunan untuk entrance utama untuk sisi kiri massa terdapat area gym, massa di tengah merupakan healthy café, untuk massa di sisi kanan merurpakan area kelas sepeda statis dan komunitas gowes. Lantai dasar proyek ini dibuat untuk area jogging track sekaligus bike track untuk mewadahi masyarakat yang memiliki hobi baru seperti jogging dan bersepeda. Pada lantai dasar juga terdapat area café dan toko rental sepeda untuk digunakan di bike track jika pengguna bangunan tidak membawa sepeda ke bangunan ini selain itu juga terdapat healthy café sehingga pengujung dapat mengkonsumsi makanan yang sehat setelah berolaharaga dan juga minimarket untuk keperluan lain-lain pengujung.

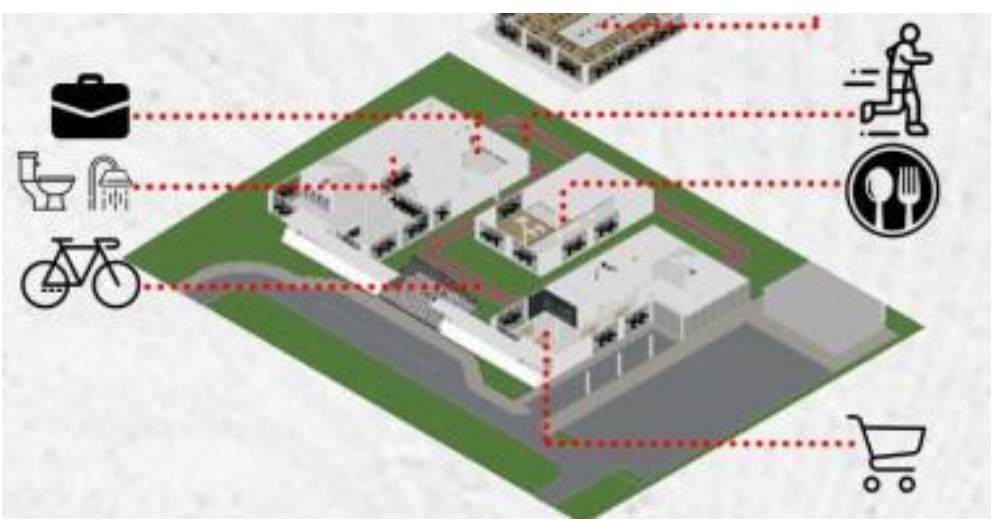

Gambar 9. Axonometri Site Plan

Sumber: Penulis, 2020 
Pada lantai 2, untuk massa bangunan kiri terdapat toko suplemen dan ruang kelas multifungsi untuk berbagai macam kelas olahraga seperti yoga, zumba, TRX, dan lain-lain. Untuk massa bangunan di tengah merupakan lantai 2 dari healthy café, sementara massa di paling kanan merupakan kelas sepeda statsis.

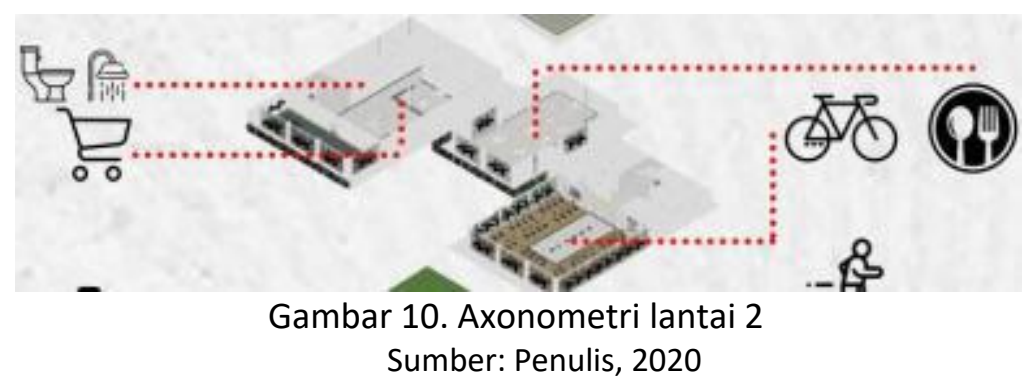

Pada lantai 3, massa bagian kiri merupakan area gym, dengan alat-alat mesin beban, dan area treadmill untuk kegiatan olahraga cardio. Sementara untuk massa bagian kanan merupakan area roofgarden yang berfungsi sebagai rooftop cycling area, yang diakses dengan menggunakan lift sehingga pengujung dapat dengan mudah membawa sepeda ke area ini tanpa harus naik tangga.

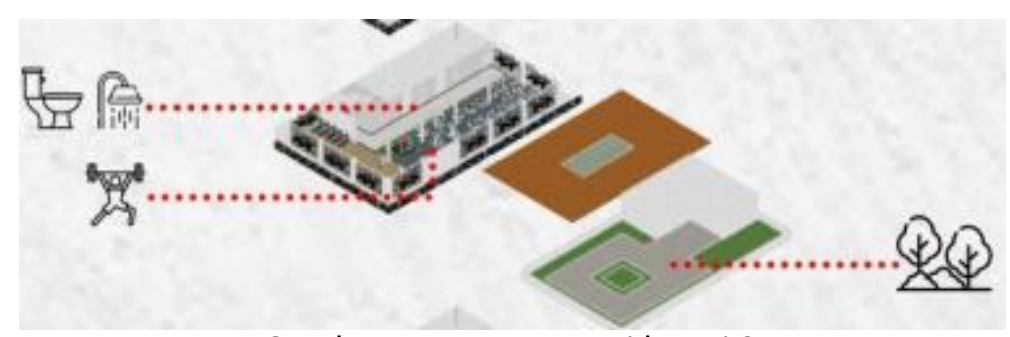

Gambar 11. Axonometri lantai 3

Sumber: Penulis, 2020

Pada lantai 4 massa kiri merupakan area gym dengan system VR training treadmill, dan juga terdapat area free weights (barbell dan dumbell) selain itu juga disediakan alat mesin beban berbasis kabel. Dan di rooftop garden merupakan area outdoor training sehingga pengguna bangunan juga bisa merasakan suasana outdoor ketika berolahraga di gym. Kegiatan olahraga yang dapat dilakukan di rooftop garden adalah olahraga senam, olahraga kalistenik, yoga, dan lainnya.

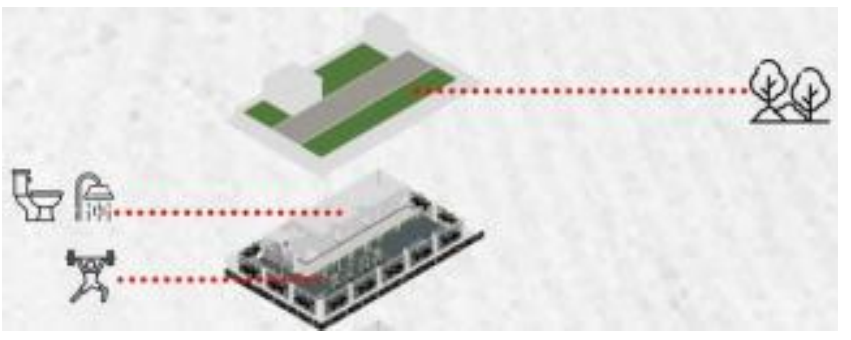

Gambar 12. Axonometri lantai 4 dan Rooftop Sumber: Penulis, 2020

Pada area jogging track dan bike track diberikan batas pemisah jalan agar orang-orang yang jogging tidak tertabrak oleh pengguna bike track. Rute pada area jogging track mengelilingi seluruh massa bangunan sehingga memiliki rute yang cukup jauh sehingga pengguna bangunan dapat melakukan kegiatan jogging sambil menikmati pemandangan yang ada di sepanjang rute. 


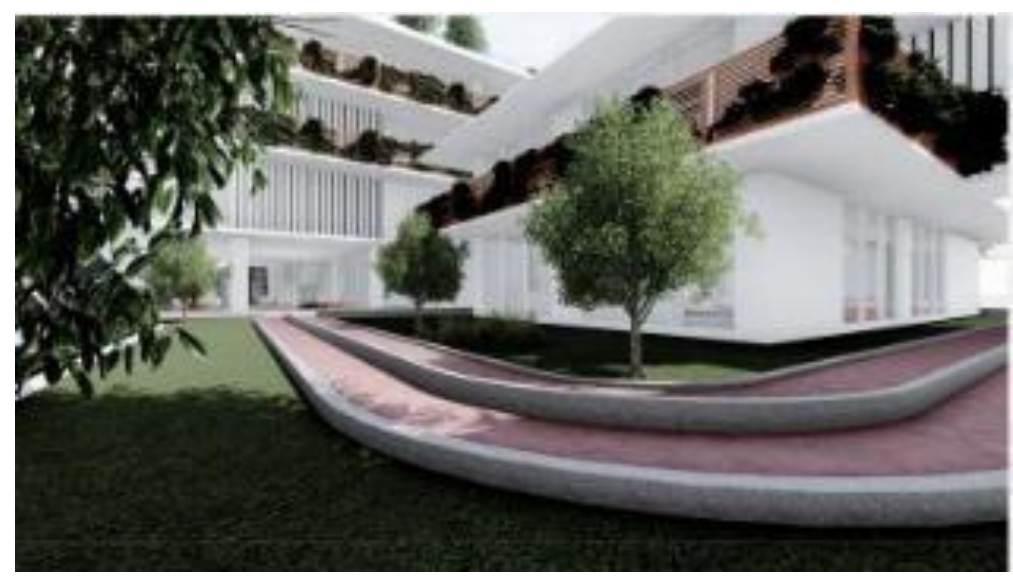

Gambar 13. Jogging Track dan Bike Track Sumber: Penulis, 2020

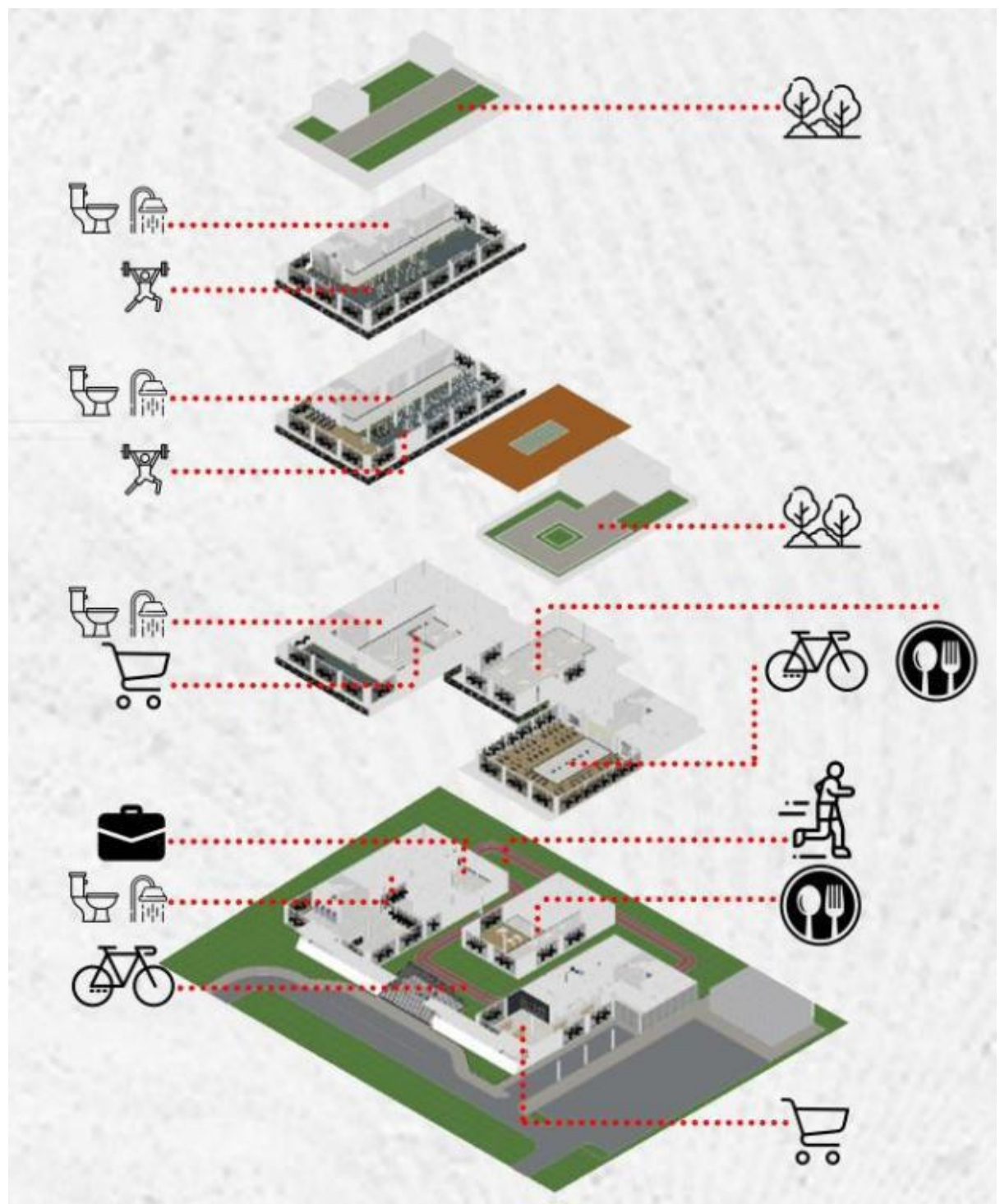

Gambar 14. Axonometri Bangunan

Sumber: Penulis, 2020 

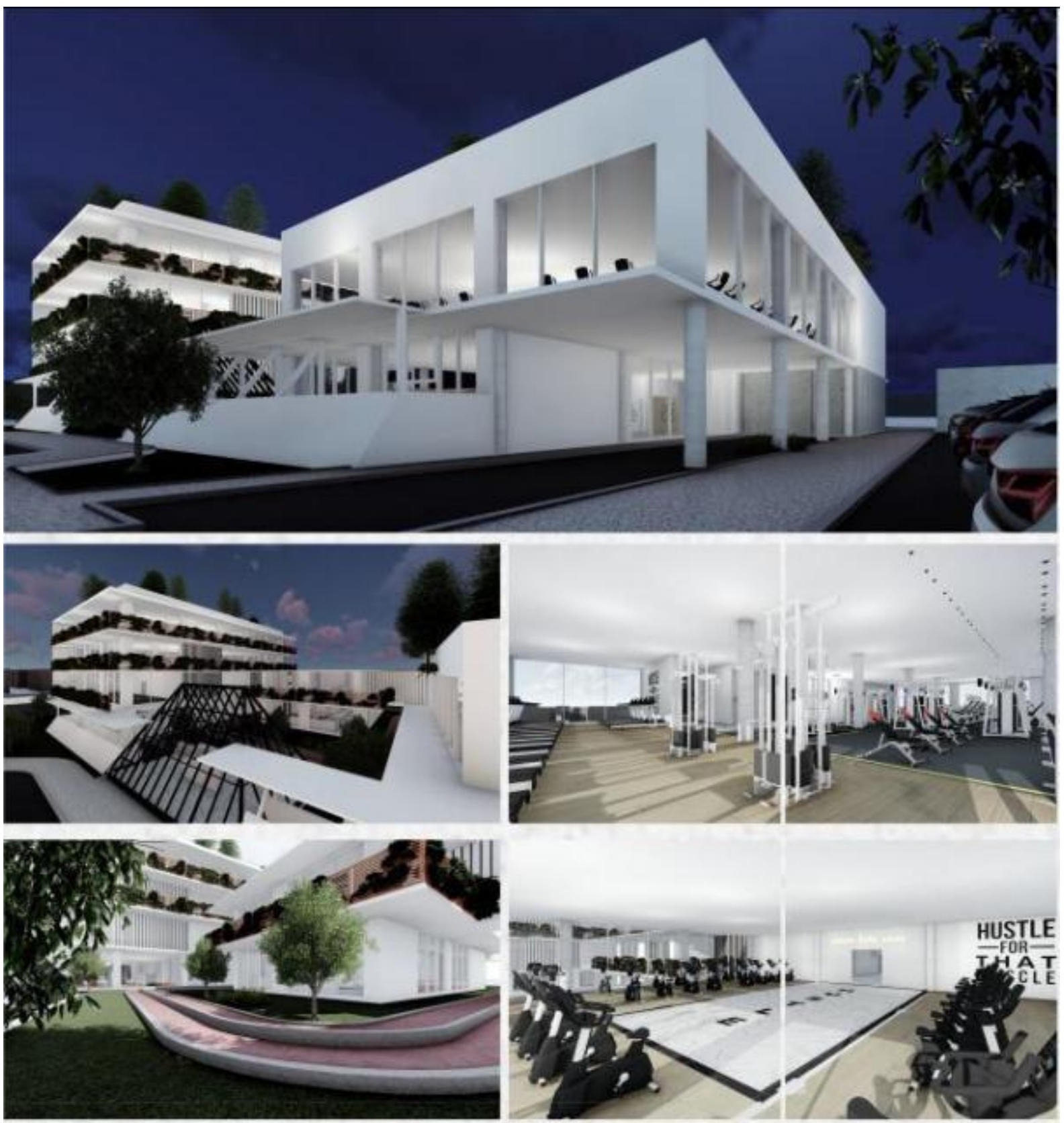

Gambar 15. Perspektif Eksterior dan Interior

Sumber: Penulis, 2020

\section{KESIMPULAN DAN SARAN \\ Kesimpulan}

Kesimpulan dari proyek ini adalahnya, karena adanya pandemi COVID-19 menyebabkan fenomena kenormalan baru, dimana diterapkannya social distancing, PSBB, dan lainnya sehingga memberi dampak terhadap pola hidup dan perilaku masyarakat, mulai dari menjaga kebersihan, jarang beraktivitas fisik, mulai melakukan pola hidup sehat, dan munculnya tren-tren olahraga seperti bersepeda. Masyarakat membutuhkan fasilitas olahraga yang tanggap terhadap pandemi COVID-19 dimana diperlukan desain gym, jogging track, dan lainnya yang dapat mencegah penyebaran virus saat pengunjung menggunakan fasilitas-fasilitas yang disediakan di dalam bangunan ini, sehingga masyarakat nyaman dalam menggunakan fasilitas ini. Tempat ini juga dibuat untuk mewadahi hobi bersepeda masyarakat, terutama masyarakat Jakarta Utara yang memiliki minat olahraga tertinggi dibandingkan wilayah lainnya. 


\section{REFERENSI}

CDC. (2020, Desember 11). Pandemics can be stressful. Retrieved from Centers for Disease Control and Prevention: https://www.cdc.gov/coronavirus/2019-ncov/daily-life-coping/managing-stressanxiety.html

Excercise is Essential for Well-Being During COVID-19 Pandemic. (n.d.). Retrieved from Nuvance Health: https://www.nuvancehealth.org/coronavirus/exercise-is-essential-for-well-being-during-covid19- pandemic/

Fleming, S. (2020, Mei 20). Weforum. Diambil kembali dari World Economic Forum: https://www.weforum.org/agenda/2020/05/five-charts-coronavirus-covid-19-behaviour/

Giambattista, M. (2020, Mei 14). The COVID-199 Lifestyle Changes Survey - What We've Learned So Far. Retrieved from The Customer: https://thecustomer.net/the-covid-19-lifestyle-changes-survey-whatweve-learned-so-far/

Heidegger, M. (1962). Being and TIme Translated by John Macquarrie \& Edward Robinson. New York: Harper. Heidegger, M. (n.d.). Building, Dwelling, Thinking: Translation and Commentary by Adam Bobeck.

Jormakka, K. (2008). Basic Design Method. Basel: Birkhäuser

Norberg-Schulz, C. (1985). The Concept of Dwelling: On the way to figurative architecture. New York: Rizzoli, International Publications, Inc.

Noya, D. A. (2018, November 27). Hormon Endorfin: Penghilang Stres dan Pereda Rasa Sakit Alami. Retrievedfrom Alodokter: https://www.alodokter.com/hormon-endorfin-penghilang-stresdan-pereda-rasa- sakit-alami\#: :tex

SEO, R. (2020, April 21). COVID-19: Changing Consumer Behavior \& How It Affecst Brands (Infographic). Retrieved from Rioseo: https://www.rioseo.com/infographics/covid-19-changing-consumer-behaviorhow-it-affects-brands-infographic/

Team, H. E. (2019, February 14). 6 Alasan Mengapa Olahraga Amat Penting. Retrieved from Honestdocs: https://www.honestdocs.id/6-alasan-mengapa-olahraga-amatpenting\#: :text=Tubuh\%20membutu 
